\title{
Structure and Function of the Lipolysis Stimulated Lipoprotein Receptor
}

\author{
Christophe Stenger, Catherine Corbier and Frances T. Yen \\ EA4422 Lipidomix and UR AFPA, ENSAIA, INPL, University of Lorraine
}

France

\section{Introduction}

\subsection{Role of lipoproteins}

Lipoproteins provide the means of transport of hydrophobic lipids in the circulation (Havel \& Kane, 1995). Composed of a single monolayer of phospholipids surrounding a neutral lipid core, the primary purpose of these spherical lipid particles is to deliver two major classes of lipids - cholesterol and fatty acids (FA) - to the different peripheral tissues. Cholesterol is carried in the form of free unesterified form in the phospholipid monolayer, or as cholesteryl esters (CE) in the nucleus of the lipoprotein. FA are transported in the form of triglycerides (TGs), also found in the hydrophobic core of the lipid particles along with the CE. Proteins that are amphipathic in nature are found associated with the lipoprotein and are referred to as apolipoproteins (apo). They serve as cofactors for lipid-modifying enzymes and proteins, including lipoprotein lipase, hepatic lipase, lecithin-cholesterol acyltransferase and cholesteryl-ester transfer protein. Apolipoproteins also serve as ligands that bind to specific sites of lipoprotein receptors, providing a means by which the lipoproteins are bound and then internalized through endocytosis via these receptors located on cell surface membranes.

\subsection{Triglyceride-rich lipoproteins}

TGs transported by lipoproteins can be either of endogenous or exogenous origin (Figure 1). Upon absorption through the intestinal wall, dietary TGs are repackaged by the enterocyte into very large TG-rich chylomicrons containing apoB48 which are then released into the circulation (Havel \& Kane, 1995). These lipoproteins distribute their TG load to the periphery via interaction with the lipoprotein lipase $(\mathrm{LpL})$ anchored by heparan sulfate proteoglycans (HSPG) on the capillary endothelium. This enzyme catalyzes the hydrolysis of TG of the chylomicrons to free FA (FFA) which are then taken up by the peripheral tissues including adipose tissue and skeletal muscle. This process leads to a depletion of the chylomicron's neutral lipid core, resulting in the formation of smaller particles called chylomicron remnants. These particles have lower TG content due to the lipolytic action, and are enriched in $\mathrm{CE}$ as compared to the original chylomicrons. During the transformation, these smaller particles acquire apoE and exchange other apolipoproteins with other lipoprotein classes. The half-life of both chylomicrons and remnants is very 
short, reported to be less than $15 \mathrm{~min}$ in studies using radioactively-labelled retinyl palmitate (Berr \& Kern, 1984; Cortner et al., 1987). Numerous studies indicate that the principal site of removal of these residues from the circulation is the liver (Attie et al., 1982), and involves a series of complex processes in the space of Disse that include binding to HSPG, interacting with hepatic and lipoprotein lipases, and acquiring additional apoE (Mahley \& Huang, 2007). The final step culminates in the delivery to the cell through receptor-mediated endocytosis, leading to internalization and degradation of the lipid particles in the lysosomal compartment of the hepatocyte.

Very-low density lipoproteins (VLDL) are produced by the liver and transport endogenously-derived lipids (Havel \& Kane, 1995). Similar to chylomicrons, these TG-rich lipid particles deliver lipids to the peripheral tissues through the LpL system, and acquire apoE and exchange other apolipoproteins with other lipoproteins. However, in humans, it is distinguished from intestinally-produced chylomicrons in that it contains apoB-100. Upon hydrolysis of TG by LpL, VLDL is converted to intermediate-density lipoproteins (IDL), and eventually to LDL. IDL is removed quickly from the circulation, and rarely detected in plasma. LDL which contains only one apoB100 per particle displays a half-life of 3-4 days, and represents the major carrier of CE in the circulation. LDL is ultimately removed from the circulation by the liver through receptor-mediated endocytosis through the LDL-receptor (LDL-R).

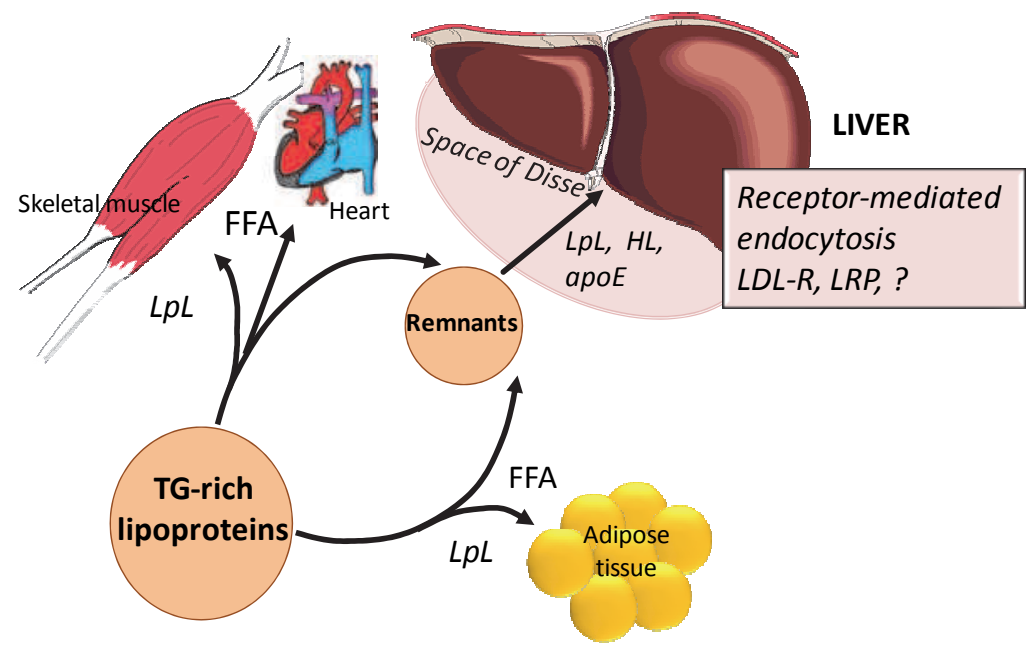

Fig. 1. General diagram for TG-rich lipoprotein processing in the circulation. Lipoproteins carrying TG of exogenous (chylomicrons) or endogenous (hepatic-derived VLDL) origins circulate in the plasma to deliver their lipids to the peripheral tissues (adipose tissue, cardiac and skeletal muscle). The lipase system consisting of lipoprotein lipase (LpL) bound to the endothelial wall hydrolyzes the TG of these particles, and the lipolytic products (FFA) are delivered to the different tissues. The resulting particles reduced in TG content (chylomicron remnants, IDL, LDL) are then taken up for catabolism by the liver through receptormediated endocytosis. Although LDL-R and LRP1 have both been implicated, evidence suggests the presence of other pathway(s) involved. 


\subsubsection{Receptor-mediated clearance of TG-rich lipoproteins}

\subsubsection{LDL-R}

A major advance was made in the lipoprotein field by the discovery of the LDL-R by MS Brown and JL Goldstein (Brown \& Goldstein, 1986; Goldstein \& Brown, 2009). Their Nobel-prize winning research clearly showed the pivotal role of this receptor in body cholesterol homeostasis (Brown \& Goldstein, 1997). The LDL-R that is defective in subjects with familial hypercholesterolemia (FH) (Goldstein et al., 1995) accounts for most of LDL removal. Although this receptor binds to both apoB100 and apoE, it does not seem to be the principal pathway for the removal of chylomicrons and their remnants. Indeed, clearance of chylomicron remnants proceeds at normal rates in humans and animals with genetic lesions impairing LDL-R function (Kita et al., 1982; Rubinsztein et al., 1990). Transgenic studies using LDL-R-/- mice nevertheless indicate that the LDL-R does participate, albeit partially to the clearance of chylomicron remnants (de Faria et al., 1996; Ishibashi et al., 1996).

The identification of the receptor(s) involved with the LDL-R in the liver-specific capture of chylomicrons has remained a difficult task, and has been a subject of many lively debates. Initial efforts resulted in the identification of apoE-binding proteins not directly involved in receptor-mediated endocytosis of lipoproteins (Beisiegel et al., 1988). Other potential candidates proposed were later found not to be expressed in the liver such as the VLDLreceptor and macrophage TG-rich lipoprotein receptor (Ramprasad et al., 1995; Sakai et al., 1994). A candidate receptor that has received the greatest attention is the LDL-receptor related protein, LRP1, which belongs to the LDL-R family (Herz et al., 1988).

\subsubsection{LRP1}

LRP1 was originally discovered by cloning based on homologous recombination (Herz et al., 1988). Because of its shared domains to the LDL-R, its primary role was thought to be in the removal of lipoproteins from the circulation. Studies revealed that while this protein cannot bind LDL, it could recognize and bind $\beta$-VLDL isolated from cholesterolfed rabbits, but only when these lipid particles are enriched with added exogenous recombinant apoE (Kowal et al., 1989). It was later revealed that LRP was in fact the alpha2-macroglobulin receptor (Strickland et al., 1990), with multiple ligands including among others, activated macroglobulin, tissue-type (tPA) and urokinase (uPA) plasminogen activators, coagulation factors IXa, VIIIa, VIIa, TFPI, complement C3, and thrombospondin-1 (Herz \& Strickland, 2001). LRP plays an important role in physiology since the absence of both alleles is embryonic lethal in mice (Herz et al., 1992). However, no remnant accumulation was observed in hepatic LRP1-inactive mice, and only a modest increase in apoB48-containing lipoproteins was observed when both hepatic LRP1 and LDL-R were inactive, suggesting that LRP plays a back-up role in the uptake of lipoproteins in the absence of the LDL-R (Rohlmann et al., 1998). Furthermore, LRP1 binds both apoE2/2 and apoE3/3 isoforms equally well (Beisiegel et al., 1989), which could not completely explain the mechanisms underlying type III hyperlipidemia which is often associated with the apoE2/2 phenotype (Soutar, 1989).

Recent evidence has shown that LRP1 selective inactivation in adipose tissue increases LpL activity, but prevents uptake of TG in adipose tissue, thereby preventing weight gain and 
insulin resistance (Hofmann et al., 2007). The authors propose that LRP1 mediates uptake of chylomicrons by adipocytes, and that this accounts for a large part of dietary TG clearance. However, it is difficult to imagine chylomicrons gaining direct access to adipocytes since unlike the liver with its space of Disse, the capillary endothelium is not fenestrated, therefore limiting access of these large bulky particles. The data nevertheless clearly show that LRP1 is necessary for proper processing of functional LpL. In absence of LRP1, the enzyme is present, but fails to deliver lipid to the underlying adipose tissue. If this is indeed the function of LRP1 in adipose tissue, this might also be the case for LRP1 in the liver. Thus, the modest hyperlipidemic effect in hepatic LRP and LDL-R inactive mice could be explained by mechanisms other than impaired receptor-mediated endocytosis, but rather by those involving LpL function. Other pathways as yet unidentified were clearly involved in the removal of TG-rich lipoproteins.

This chapter focuses on the biochemical characterization, identification and function of the lipoprotein receptor which plays an important role in the removal of TG-rich lipoproteins during the postprandial phase.

\section{Biochemical characterization of LSR}

\subsection{Original identification and characterization of an LDL-receptor independent pathway in LDL-receptor negative fibroblasts from a subject homozygous for familial hypercholesterolemia}

A study by Bihain et al revealed that FFA could regulate lipoprotein receptor activity, by showing that FFA inhibit binding of LDL to its receptor (Bihain et al., 1989). During these studies, it was discovered that in the presence of oleate, fibroblasts from a patient homozygous for familial hypercholesterolemia (FH fibroblasts) and therefore deficient in LDL-R were able to internalize a significant amount of LDL. A series of experiments were conducted to biochemically characterize this pathway apparently independent of the LDL-R (Bihain \& Yen, 1992). The uptake of ${ }^{125}$ I-radiolabelled LDL increased in a dosedependent manner with the concentration of oleate used. The first question was to ask if cell viability was modified by the presence of FFA, which was not the case. Kinetic studies revealed that the internalization of LDL was time and dose-dependent, where saturation was achieved at $50 \mu \mathrm{g}$ LDL protein/ml. Degradation products, measured as TCA-soluble 125I released into the media appeared approximately $30 \mathrm{~min}$ after addition of oleate, which corresponds closely to the time required for delivery of ligands to the lysosome after internalization. Chloroquine, which is an inhibitor of lysosomal enzymes, prevented the appearance of ${ }^{125} \mathrm{I}$-products, confirming that the ${ }^{125} \mathrm{I}$-LDL internalized was delivered to the lysosome for degradation. It therefore appeared that the uptake of LDL into the cell through this LDL-receptor independent pathway was achieved through endocytosis, implying the presence of a receptor binding site of a specific nature on the cell surface plasma membrane (Bihain \& Yen, 1992).

Different FFAs were used to ascertain the nature of the potential binding site on the plasma membranes of the FH fibroblasts. It was found that the addition of a double bond rendered the FFA more efficient in activating this LDL-R independent pathway, as compared to the corresponding saturated analogs (Bihain \& Yen, 1992). Interestingly, oleate, one of the more abundant FFA in plasma was found to be the most efficient 
activator of this pathway. FFA analogs with uncharged residues such as oleyl alcohol or oleyl acetate also demonstrated a similar effect on LDL internalization, although slightly less efficient as compared to oleate (Bihain \& Yen, 1992).

Binding studies at $4^{\circ} \mathrm{C}$ revealed that in the presence of oleate, 125I-LDL bound with high affinity to a saturable and specific binding site on FH fibroblasts (Bihain \& Yen, 1992). Bound LDL could be released by suramin, a polysulfated aromatic sodium salt, much in the same manner that heparin is used to release LDL bound to the LDL-R (Bihain \& Yen, 1992). By comparing the amount of LDL bound to this oleate-induced binding site at $4^{\circ} \mathrm{C}$ to that released by suramin, it was determined that suramin released lipoprotein that was specifically bound to the cell surface. Treatment of cells with suramin during incubations with oleate and ${ }^{125}$ I-LDL simultaneously prevented the accumulation of cellular ${ }^{125}$ I-LDL as well as TCA soluble products, demonstrating that this binding site, once occupied by the ligand LDL, mediates internalization and subsequent degradation of the lipoprotein in the lysosome. Scatchard analysis of binding curves revealed characteristics of a single binding site with a $\mathrm{Kd}$ of $12.3 \mu \mathrm{g} / \mathrm{ml}$ and Bmax of $78.4 \mathrm{ng}$ of LDL protein.

Competition studies indicated that this binding site displayed a higher affinity for the TG-rich VLDL as compared to LDL (Bihain \& Yen, 1992). This affinity for VLDL was directly related to the size of the particle and therefore TG content of the VLDL fraction, with the highest affinity being for the larger $\mathrm{VLDL}_{1}$ fraction, as compared to that for $\mathrm{VLDL}_{2}$ and $\mathrm{VLDL}_{3}$. Further studies revealed that chylomicrons or lipid emulsions containing recombinant apoE could compete with 125I-LDL for binding in the presence of FFA (Yen et al., 1994). Digestion of apoB100 on the LDL with mild pronase treatment renders the LDL unable to bind this oleateinduced binding site, thus clearly demonstrating a direct protein-protein interaction between the lipoprotein ligand and the cell surface binding site. Derivatization of LDL with cyclohexanedione (CHD) modifies arginine residues of apoB resulting in a CHD-LDL unable to bind the LDL-R. Interestingly, CHD-LDL was able to compete for binding with ${ }^{125}$ I-LDL as well as normal unlabeled LDL. This modified LDL has been used to demonstrate the presence of a LDL-receptor independent pathway in human subjects (Simons et al., 1975), suggesting that perhaps this binding site may be involved in LDL-R-independent clearance. Finally, removal of cell surface proteins by mild trypsin treatment of the cell surface eliminated the cell's capacity to exhibit oleate-induced binding, uptake and degradation of 125I-LDL (Bihain \& Yen, 1992), clearly showing the protein nature of this cell binding site.

Taken together, the initial characterization of this LDL-receptor independent pathway revealed that the FFA-induced binding, internalization and degradation of LDL was mediated by protein-protein interaction with a cell surface protein that recognized either apoB100 or apoE. Binding of the lipoprotein to this binding site in the presence of FFA leads to endocytosis, ultimately leading to lysosomal degradation of the lipoprotein particle.

\subsection{Identity of the lipolysis stimulated lipoprotein receptor, LSR distinct from LDL-R and LRP}

In view of the cell type used in these studies, it was clear that this binding site was not the LDL-R itself. Indeed, in FH fibroblasts, due to a significant deletion of the promoter region, these cells are unable to synthesize the LDL-R (Hobbs et al., 1987). Furthermore, it was previously demonstrated that FFA inhibit binding of LDL to the LDL-R. Other data that 
characterize LDL binding outside of the cell using liver membrane assays described later will further confirm the distinct identity from the LDL-R of this FFA binding site. LDL was nevertheless used in these assays for technical reasons. First of all, LDL is easily isolated from human plasma in sufficient quantities for the type of studies that were performed. Secondly, LDL contains only one molecule of the large $500 \mathrm{kDa}$ apoB100 that does not dissociate from the lipoprotein particle. Therefore, the ${ }^{125}$ I-radiolabel on the apoB100 of LDL provides an accurate measurement of the amount of lipoprotein particle itself bound, internalized and degraded by the cells. This is unlike the TG-rich lipoproteins, chylomicrons and VLDL, which contain a number of different apolipoproteins including apoE, as well as the apoA- and the apoC-classes of apolipoproteins. These apolipoproteins readily exchange between different lipoprotein particles, rendering it difficult to precisely measure the kinetics of the endocytosis. It was therefore deliberately chosen to continue using LDL as a ligand to study this pathway.

At the time, the LRP1 had been cloned and then identified as being $100 \%$ homologous to the $\mathrm{a}_{2}$-macroglobulin receptor. Questions arose as to whether this oleate-induced binding site could be LRP1. A number of evidence indicated that such was not the case. While it was necessary to supplement $\beta$-VLDL with exogenous recombinant apoE before binding by LRP, this was not necessary for $\beta$-VLDL binding in the presence of oleate in FH fibroblasts (Bihain \& Yen, 1992). Experiments using activated $a_{2}$-macroglobulin as a known LRP ligand demonstrated that there was no effect of oleate on LRP-mediated internalization and degradation of this ligand (Yen et al., 1994). Nor was the oleate-induced receptor inhibited by the $39 \mathrm{kDa}$ receptor-associated protein (RAP) at concentrations shown to affect LRP activity (Yen et al., 1994). Furthermore, it had been shown that LRP was able to bind and recognize apoE2/2 (Beisiegel et al., 1989), while this oleate-induced pathway for lipoproteins was unable to bind to VLDL isolated from a type III hypertriglyceridemic patient with the apoE2/2 phenotype (Yen et al., 1994).

Biochemical characterization of both receptors therefore revealed two distinct identities. It is interesting to note the two different approaches used to identify these two receptors. LRP was cloned based on its homology to specific domains of the LDL-R. The biochemical characterization of LRP revealed a multiligand receptor, for which lipoproteins were not necessarily the most important of ligands. Indeed, there are now numerous members of the LDL-R family that have been identified, all exhibiting diverse functions in physiology, at the level of both periphery and central nervous system (Herz \& Strickland, 2001). While the protein and gene had been identified, it remained to determine the actual physiological role in lipoprotein metabolism of this receptor related to LDL-R. On the other hand, LSR was first identified and characterized functionally, as a receptor on the cell surface able to bind, internalize and degrade lipoproteins in the presence of FFA. It remained to identify the protein and gene responsible, in order to validate the physiological role of this receptor.

By virtue of its activation by FFA, it was thought that this receptor would be active primarily during times when lipolysis is active, in other words during postprandial lipemia when there is increased levels of chylomicrons in the circulation. Indeed, lipases on the endothelial wall hydrolyze TG of chylomicrons and VLDL, two classes of lipoproteins that display the highest affinity for this LDL-receptor independent pathway. Because of this lipolysis-dependent step, the as yet unidentified receptor responsible for this pathway was named the lipolysis stimulated lipoprotein receptor, or LSR. 


\subsection{LSR in the hepatocyte}

\subsubsection{Biochemical characterization of hepatic LSR}

The clearance of chylomicrons has previously been shown to take place in the liver through a receptor-mediated process (Sherrill \& Dietschy, 1978). The LSR model had been biochemically characterized in FH fibroblasts, much in the same way as the LDL-R had been identified in normal human fibroblasts. Studies revealed that LSR activity was indeed found in primary cultured hepatocytes (Yen et al., 1994). However, although LDL cannot bind LDL-R in the presence of FFA, LDL-R activity in liver cells in the absence of oleate yielded interpretation of results difficult at times. Assays were developed using cell-free liver membranes in order to directly measure binding of lipoproteins to LSR. Binding studies using isolated liver total or plasma membranes revealed that LSR binding to ${ }^{125}$ I-LDL in the presence of oleate was $\mathrm{Ca}^{2+}$-independent (Mann et al., 1995). Indeed, LDL-R being a $\mathrm{Ca}^{2+}$ dependent receptor (Goldstein et al., 1983), this provided additional evidence for the distinct identity between LSR and LDL-R.

Further biochemical characterization using these assays revealed that the binding characteristics were similar to those observed for FH fibroblasts (Yen et al., 1994). Saturated FFA were less efficient in the activation of LSR as compared to oleate. Scatchard plots revealed again a single binding site with half maximum binding occurring at $23 \mu \mathrm{g}$ LDL protein/ml. Heparan sulfate proteoglycans had been previously speculated to play a role in endocytosis of TG-rich lipoproteins (Eisenberg et al., 1992; Mulder et al., 1993; Williams et al., 1992). However, pretreatment of isolated liver membranes with heparinase/heparitinase and chondroitanase had no significant effect on oleate-induced binding of 125 I-LDL to LSR, unlike trypsin, which diminished LSR activity in a timedependent manner leading to the disappearance of receptor binding after 60 minute treatment (Mann et al., 1995). Perfusion of livers with trypsin to degrade cell surface proteins before preparation of membranes also significantly diminished LSR binding activity by $80 \%$, demonstrating that the majority of LSR activity measured occurs on the cell surface exposed on the extracellular side (Mann et al., 1995).

\subsubsection{Reversibility of LSR activation by FFA}

The development of these liver membrane assays allowed closer examination of the activation of LSR by FFA. Experiments revealed that the activation of LSR by FFA is reversible, but only if the binding site remains unoccupied (Mann et al., 1995). Albumin provided a means to remove FFA from the membranes after the activation step. Indeed, if membranes were washed with buffer containing albumin after incubation with oleate, binding of the lipoprotein to LSR did not occur. If after one series of activation by oleate and deactivation using albumin were performed, it was still possible to wash the membranes to remove the albumin, and then re-incubate the membranes in the presence of oleate with ${ }^{125}$ I- LDL. Binding of the lipoprotein to LSR was detected, indicating that FFA binding is reversible. However, if liver membranes are incubated with oleate, followed by the radiolabelled lipoprotein, the LSR-LDL binding complex remains stable. Washing with even very high concentrations of albumin after formation of the LDL-LSR complex is unable to dissociate the ligand from the receptor. These results suggested a reversible conformational change of LSR in the presence of FFA that reveals the apoB, apoE binding site. Once the ligand-receptor complex is formed, this appears to stabilize 
the active LSR conformation. It is also possible that the FFA associated with the receptor or the surrounding phospholipid environment may be trapped within the complex, and inaccessible to the albumin in the washing buffer. These potential mechanisms remain to be tested in isolated systems using purified receptor.

\subsection{In vitro evidence for this receptor's role in the hepatic clearance of triglyceride- rich lipoproteins}

A number of circumstantial evidence for LSR's potential role in hepatic clearance of lipoproteins was brought to light using these cell and membrane assays for LSR activity in the liver. Indeed, the measure of oleate-induced ${ }^{125}$ I-LDL binding under conditions in which maximal binding capacity of LSR is achieved represents an estimation of the apparent number of LSR on the hepatocyte membrane. Rats were sacrificed under non-fasted and fasted conditions, and plasma hepatocyte membranes isolated to measure maximal LSR binding activity. A strong negative correlation $(r=-0.828, p<0.001)$ was observed between the apparent number of LSR on the cell surface and the plasma TG levels measured at the time of the sacrifice of the animals (Mann et al., 1995). This implied that the higher LSR binding activity was, the lower the plasma TG levels. On the other hand, under fasting conditions, there was no significant correlation between these 2 parameters. Therefore, even in a normal sample population of laboratory rats, the variation in LSR corresponds to their ability to remove TG from the circulation, but only during the fed or postprandial state. This was the first in vitro circumstantial evidence pointing towards a potential role of LSR as a rate limiting factor for the removal of TG-rich lipoproteins during the postprandial phase.

\subsubsection{Lactoferrin}

Studies in the literature on the regulation of postprandial lipemia demonstrated that the milk protein, lactoferrin, when injected iv in rats led to increased TG during the postprandial phase by inhibiting clearance of chylomicrons (Huettinger et al., 1988). Indeed, lactoferrin contains a cluster of arginine residues, which is also found in the apoE binding site for the LDL-R. Further investigation showed that while lactoferrin delays chylomicron remnant clearance, it has no effect on $\mathrm{a}_{2}$-macroglobulin uptake in the liver, which is one of the principal ligands of LRP as discussed in an earlier section. Lactoferrin was found to inhibit LSR activity as a lipoprotein receptor in FH fibroblasts (Yen et al., 1994) and LSR binding activity in liver membranes (Mann et al., 1995). It was also observed that lactoferrin's inhibitory effect was present only if LSR was in its FFA-activated form. Indeed, the presence of lactoferrin before addition of oleate had no effect on LSR's ability to bind the lipoprotein ligand. Levels of membrane-associated oleate was not altered in the presence of lactoferrin, demonstrating that lactoferrin did not inhibit LSR activity by binding or removing FFA from the membranes (Mann et al., 1995). This supports the earlier data described above suggesting two distinct conformations of LSR, one conformation of the receptor in the absence of oleate, and a different conformation in the presence of oleate.

\subsubsection{ApoCIII}

ApoCIII is an apolipoprotein associated with TG-rich lipoproteins that plays a role in the modulation of plasma TG levels as a lipase inhibitor. Delayed clearance of TG-rich lipoproteins has been observed in mice overexpressing apoCIII (Aalto-Setala et al., 1992; Ito 
et al., 1990). In addition, targeted disruption of apoCIII gene in mice leads to increased removal rates of chylomicron remnants associated with reduced TG levels during the postprandial phase (Maeda et al., 1994). Supplementation of VLDL with apoCIII led to decreased binding and uptake through the LSR pathway in primary cultures of rat hepatocytes (Mann et al., 1997). This was in contrast to apoCII, which displayed no such impact on VLDL binding to LSR. Furthermore, the degree of sialyation of apoCIII appeared to influence its ability to inhibit VLDL binding to this receptor (Mann et al., 1997). Therefore, the hypertriglyceridemic effect reported for apoCIII may be due in part to its inhibition of binding of VLDL to the LSR receptor, resulting in reduced hepatic capacity for the removal of TG-rich lipoproteins from the circulation.

\subsubsection{9 kDa receptor-associated protein}

Finally, the $39 \mathrm{kDa}$ receptor-associated protein (RAP) is a protein that co-purifies with LRP1, and which was shown to inhibit binding of LRP ligands to their receptor (Herz et al., 1991; Moestrup \& Gliemann, 1991; Williams et al., 1992). RAP overexpression using adenovirus vector in wild-type and LDL-R $/$ - mice led to an accumulation of plasma cholesterol and TG, as well as apoB-48 and apoE particles (Willnow et al., 1994). In this model, RAP levels were increased to a large extent in the animals. It was found that RAP, at concentrations similar to those used in this animal study inhibited oleate-induced binding, uptake and degradation of 125 I-LDL through the LSR pathway (Troussard et al., 1995). Lineweaver-Burk analysis revealed that this was due to a change in maximal binding capacity, rather than to a change in affinity (Troussard et al., 1995). Other studies also reported that at these levels, RAP could also affect LDL-R activity (Medh et al., 1995; Mokuno et al., 1994), therefore showing that the modifications in plasma lipids in RAPoverexpressed mice were most likely to be due to inhibition of multiple lipoprotein receptors, rather than just LRP1 alone.

The use of the different proteins that modulate TG and postprandial lipemia revealed a number of in vitro circumstantial evidence for the potential physiological role of LSR. Indeed, each protein shown to demonstrate a hypertriglyceridemic effect was determined to influence LSR activity as a lipoprotein receptor, whether directly on the receptor or indirectly through ligand binding to LSR. With this circumstantial evidence pointing towards a role of LSR in the removal of TG-rich lipoproteins during the postprandial phase, it remained to actually identify the protein or proteins responsible for LSR activity.

\section{Molecular characterization of LSR}

\subsection{Purification of LSR}

Ligand blots were performed using human FH fibroblast lysates, in which cell lysate proteins were separated by SDS-polyacrylamide gel electrophoresis under non-reducing conditions, and then transferred to nitrocellulose (Yen et al., 1994). Interestingly, binding of 125I-LDL in the presence of oleate was observed for 2 protein bands migrating at apparent molecular mass of 115 and $85 \mathrm{kDa}$. Mild trypsin treatment of cells before preparation of cell lysates demonstrated that these 2 proteins were located on the cell surface. These ligand blots were performed in the absence of $\mathrm{Ca}^{2+}$, which therefore eliminated the possibility that LDL was binding to the $\mathrm{Ca}^{2+}$-dependent LDL-R. 
Upon identification of LSR activity in rat hepatocytes, liver membranes were prepared followed by treatment with n-octylglucoside (Mann et al., 1995), a mild non-ionic detergent often used to solubilize integral membrane proteins. An LSR-enriched fraction was prepared following further purification of the solubilized protein fraction by anion exchange chromatography, and was tested in ligand blots. These binding studies again revealed 2 bands at 115 and $90 \mathrm{kDa}$. A third band was also observed at around $230 \mathrm{kDa}$, which could represent either a homodimeric form of the $115 \mathrm{kDa}$ band, or a heterodimeric form of the two lower molecular mass bands (Mann et al., 1995). The results of these ligand blots did reveal that this receptor, even when immobilized on nitrocellulose could be activated by oleate in absence of the phospholipid environment. This would therefore be consistent with the previous data suggesting a conformational change in the protein occurring following direct interaction of the FFA with the LSR proteins rather than with the surrounding membrane bilayer.

The ligand blots allowed the study of LSR protein interaction with other proteins, including the $39 \mathrm{kDa}$ RAP (Troussard et al., 1995). Using a recombinant $39 \mathrm{kDa}$ RAP fusion protein, it was found that this protein could bind directly to the same bands identified as displaying LSR binding activity. Interestingly, this binding did not require oleate. Furthermore, although preincubation with high concentrations of RAP fusion protein inhibited binding of the LDL ligand to oleate-activated LSR, LDL was unable to compete for RAP fusion binding to LDL. This suggested that the LSR binding site for RAP was distinct from that for the apoB component of LDL.

\subsection{Identification and cloning of the gene candidate}

Even after having identified LSR protein bands, it proved to be very difficult to isolate the LSR receptor. Indeed, ligand blots led to the speculation that this was indeed a complex composed of multiple subunits. It was discovered that the protein migrating around 240 $\mathrm{kDa}$ rapidly degraded into multiple bands of different molecular masses once removed from the membrane phospholipid environment (Mann et al., 1995; Yen et al., 1999). Because of the lability of this complex, the purification of sufficient quantities in reduced form with adequate purity for microsequencing ended up being a major obstacle. Indeed, it was difficult to isolate the different bands from other contaminating proteins of similar molecular masses. Antibodies were prepared against the large $240 \mathrm{kDa}$ complex by splicing out the band directly from the SDS gel and injecting into rabbits (Yen et al., 1999). These antibodies were validated in Western blots, identifying the same proteins also shown to bind radiolabelled LDL in the presence of oleate in corresponding ligand blots. This same antibody was also able to inhibit LSR binding activity in liver membranes, as well as LSR receptor activity in primary cultures of rat hepatocytes. Immunoprecipitation studies were performed with these antibodies using ${ }^{35}$ S-metabolically-labelled rat hepatocytes. Separation of the proteins under non-reduced conditions revealed 3 predominant bands at 240, 180 $\mathrm{kDa}$, and a third band migrating at $70 \mathrm{kDa}$ previously unidentified in ligand blots, while the 115 and $90 \mathrm{kDa}$ proteins were also present, but only as weak bands (Yen et al., 1999). Under reduced conditions, all of these bands were detected, but only weakly, and 2 principal subunit bands with the molecular mass of 68 and $56 \mathrm{kDa}$ were observed, with the $68 \mathrm{kDa}$ band appearing sometimes as a doublet. The other bands originally identified in human $\mathrm{FH}$ fibroblasts and liver membranes were therefore most likely heterotrimer or tetramers of 
these 2 subunits, hereafter referred to as a $(68 \mathrm{kDa})$ and $\beta(56 \mathrm{kDa})$, respectively. The lower molecular mass band of the doublet was referred to as $\alpha^{\prime}$. Mild trypsin treatment of the hepatocytes before preparation of the cell lysates provided evidence that these two subunits were located on the cell surface. Two-dimensional electrophoresis in which the $240 \mathrm{kDa}$ complex was separated under non-reduced conditions, then isolated and then separated under reduced conditions revealed that these 2 bands were directly derived from the larger protein complex (Yen et al., 1999).

This validated antibody was therefore used to screen a phage expression library of rat liver cDNA, from which a potential candidate gene was identified with an open reading frame within a Kozak consensus sequence (Yen et al., 1999).

\subsection{Bioinformatic analysis of the candidate gene}

Bioinformatic analysis of the predicted protein sequence of the candidate cDNA revealed a number of domains potentially indicative of a receptor (Bihain \& Yen, 1998; Yen et al., 1999) (Figure 2).

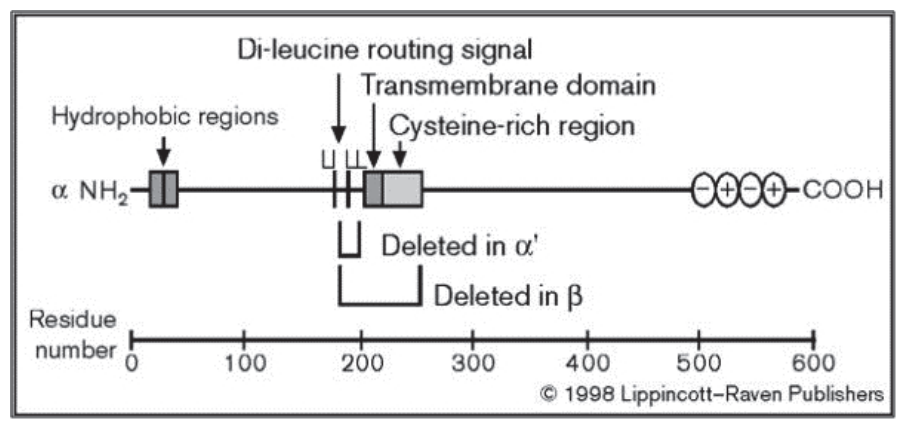

Fig. 2. Schematic diagram of the different domains of LSR. Analysis of the predicted sequence of the LSR protein shows that the longest form a contains a hydrophobic region near the $\mathrm{NH}_{2}$ terminal, a dileucine routing signal and a transmembrane domain. A cysteine-rich region is found as indicated, as well as a region rich in positively and negatively charged residues near the carboxylic end. The deletions for the forms a' and $\beta$ are also indicated (Bihain \& Yen, 1998, reproduced with permission from Lippincott-Raven Publishers).

A transmembrane domain was predicted based on the detection of an internal cluster of hydrophobic residues. Several motifs related to endocytosis were detected, including a phosphorylation site NPGY that potentially represents a clathrin-binding site (Chen et al., 1990), as well as a dileucine lysosomal targeting signal (Dietrich et al., 1994; Shin et al., 1991). Both of these domains were located on the N-terminal side with respect to the putative transmembrane domain, suggesting that the $\mathrm{N}$-terminal was exposed intracellularly. On the N-terminal side of the protein, a smaller group of hydrophobic residues separated by a proline residue was located, which could be associated with the membrane phospholipids, providing a potential site of interaction with FFA. On the Cterminal side of the transmembrane domain, a cysteine-rich region was found that is often observed in the family of cytokine receptor proteins (Bazan, 1990). On the C-terminal end of the protein was located a group of alternating negatively and positively charged amino 
acids, which could represent the lipoprotein binding site. LSR is a phosphorylated receptor, with six phosphopeptides recently identified (Villen et al., 2007), for which the function remains to be determined.

Northern blots revealed that mRNA of this candidate was detected in abundance in the liver, and in lesser levels in the kidney and lung, with none being detected in the muscle, spleen brain or heart (Yen et al., 1999). Multiple mRNAs detected in the liver led to a closer examination of the mRNA derived from this potential LSR gene. Indeed, RT-PCR using different primer sets with overlapping sequences revealed in actual fact 3 distinct mRNAs with base numbers corresponding to LSR 2097, 2040 and 1893. The predicted molecular mass for each corresponded to 65.8 , 63.8 and $58.3 \mathrm{kDa}$, respectively, matching rather closely to the 3 bands, $\alpha, a^{\prime}$ and $\beta$, identified in the previously described immunoprecipitation studies (Yen et al., 1999). The predicted sequence of a corresponds to the full length protein containing all domains described. In $\alpha^{\prime}$, the sequence is practically identical with the exception of the loss of the dileucine repeat, suggesting that the intracellular routing of this subunit may differ from that of $\alpha$. The $\beta$ subunit no longer contains the sequences for endocytosis and lysosomal targeting, the transmembrane domain and the cysteine-rich domain. This subunit however still contains both N-terminal hydrophobic domain for potential interaction with FFA or the cell membrane, as well as the C-terminal potential binding site for lipoproteins. Therefore, while the subunits a and $\alpha^{\prime}$ are associated with the phospholipid bilayer, the $\beta$ subunit, although associated with the LSR complex, may be located either extracellularly or intracellularly. The role of each 3 subunit either as individual polypeptides or as complexes associated on the cell membrane surface remains to be clearly defined.

The human lsr gene is located on chromosome 19 (19q13.12) (Bihain \& Yen, 2005)(Genbank Gene ID: 51599). Interestingly, the LDL-R is located on chromosome 19 as well, but on 19p13.2. Furthermore, the $l s r$ gene is found upstream of a number of genes involved in lipid and lipoprotein metabolism including LIPE, which codes for the hormone sensitive lipase of adipose tissue involved in the insulin-controlled FFA release from adipose tissue. Further downstream is the apoE/apoCI,CII,CIV gene cluster, in which apoE is one of the potential ligands for LSR. The lsr gene structure contains 10 exons, from which are derived 3 mRNA products, 2 of which are alternatively-spliced products. Sequence analysis revealed that the mRNA LSR 2097 ( $\alpha$ ) cited above represents the full-length sequence of all 10 exons, while the mRNA LSR $2040\left(\alpha^{\prime}\right)$ and $1893(\beta)$ represent alternatively spliced products in which either exon $4\left(\alpha^{\prime}\right)$ or exon 4 and $5(\beta)$ are deleted.

\section{Functional validation of LSR's function}

\subsection{In vitro studies}

Studies were conducted on CHO-K1 cells transiently transfected with the subunits a and $\beta$ (Yen et al., 1999). The transfection of each subunit individually led to increased binding and internalization of ${ }^{125}$ I-LDL in the presence of oleate. Only the co-transfection of both subunits completely restored LSR activity as a lipoprotein receptor leading to degradation of the lipoprotein particle. These results, along with the immunoprecipitation studies described earlier suggested that LSR present as a multimeric complex composed of at least $\alpha$ and $\beta$ serves as a receptor for lipoproteins leading to delivery of the particle to 
lysosomes for degradation via endocytosis. Each subunit appears to retain the capacity to bind the lipoprotein in the presence of oleate, consistent with the domains that are present in both polypeptides. However, the $\beta$ polypeptide does not contain the transmembrane domain, and it remains to be determined how it is expressed on the cell surface in the absence of the other LSR subunits. These functional in vitro data nevertheless supported the notion that the protein products derived from this candidate gene were responsible for LSR activity (Figure 3).

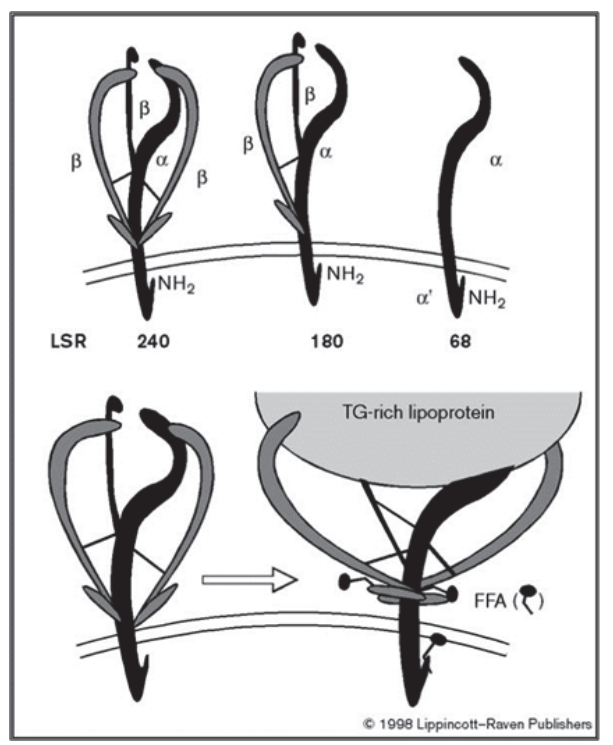

Fig. 3. Hypothetical model of lipolysis stimulated receptor and its activation by FFA. (Top panel) Analysis of both biochemical data and that from Figure 2 allows us to propose that LSR could exist on the cell surface as a multimeric complex of one $\alpha$ or $\alpha^{\prime}$ (solid) subunit containing the transmembrane domain associated by disulfide bridges with two or three $\beta$ (gray) subunits, which would be exposed completely on the extracellular side. The predicted molecular masses would be 240 and $180 \mathrm{kDa}$. It is also possible that a or a' subunits would be present alone on the plasma membrane surface. (Bottom panel) When FFAs are present, they bind to the hydrophobic regions, causing a conformational change of the LSR multimeric complex. This, in turn, exposes a binding site that, in this case, recognizes the apoE of a TGrich lipoprotein, leading to its binding, internalization and degradation. (Bihain \& Yen, 1998, reproduced with permission from Lippincott-Raven Publishers)

\subsection{In vivo studies}

The next step was then to determine LSR physiological function in an animal model. The lsr gene was inactivated in 129/Ola ES cells by the deletion of a gene segment containing exons $2-5$, and then injected into mouse embryos. Complete suppression of this gene proved to be lethal at the embryonic stage (Mesli et al., 2004). Even though 3 LSR $/$ - males were produced in the initial reproduction, they proved to be weak and sterile. Mortality of the homozygote embryos occurred between days 12.5 and 15.3 of the gestation period. Interestingly, the 
livers were abnormally small in these mice, suggesting that LSR was important for normal liver and embryonic development. Heterozygote $\mathrm{LSR}^{+} /$- mice proved however to be viable. Both immunoblots and quantitative PCR analyses demonstrated that hepatic LSR protein and mRNA were reduced by at least $50 \%$ in the LSR+/- mice (Yen et al., 2008b).

Phenotypic analysis revealed that these $\mathrm{LSR}^{+/-}$mice with reduced expression of LSR displayed both increased postprandial lipemia and reduced clearance of TG-rich lipid particles (Yen et al., 2008b). These results are striking in that even in heterozygote mice expressing only one allele, the lower expression of LSR has a considerable impact on their ability to clear lipoproteins from the circulation during the postprandial state. Interestingly, if LDL-R was also absent in $\mathrm{LSR}^{+/-}$mice, postprandial lipemia was increased almost 2-fold as compared to $\mathrm{LSR}^{+/-}$mice with normal LDL-R activity, suggesting a cooperativity between these two receptors in the removal of apoB-containing lipoproteins.

Both plasma cholesterol and TG levels increased in these mice when placed on a Westerntype diet containing high fat and cholesterol, primarily due to an increase in both TG-rich lipoproteins and LDL (Yen et al., 2008b). This was accompanied by increased lipid deposits in the aorta of the LSR ${ }^{+/-}$mice as compared to controls on the same diet, consistent with the atherogenic nature of these lipid particles. Interestingly, body weight gain of the $\mathrm{LSR}^{+/-}$but not $\mathrm{LSR}^{+/+}$mice on the Western-type diet, was directly correlated with the increased plasma lipid levels (Yen et al., 2008b). This provided clear in vivo evidence for the physiological role of LSR in lipoprotein clearance during the postprandial phase, as well as a potential link provided by this receptor that could explain mixed hyperlipidemia (hypercholesterolemia and hypertriglyceridemia), weight gain and atherosclerosis. A recent study confirmed this in which adenovirus-mediated expression of siRNA specifically targeting hepatic LSR led to a significant increase in postprandial triglyceridemia, accompanied by increased levels of both apoB and apoE (Narvekar et al., 2009).

Continued monitoring of $\mathrm{LSR}^{+/}$- mice on standard laboratory chow diet revealed significant weight gain and increased leptin with age as compared to control mice (Stenger et al., 2010). This was most marked in female LSR+/- mice, where body mass was increased 1.5 fold due to increased body fat mass, accompanied by a disproportionate 3fold increase in plasma leptin, a satiety hormone produced by the adipose tissue. Therefore, even under normal dietary conditions, a deficit in this receptor associated with elevated postprandial lipemia can lead to anomalies in both weight and plasma leptin. Indeed, hyperleptinemia is often observed in obesity, normally due to increased fat mass. It can be concluded therefore that by virtue of its role in the removal of apoB and apoEcontaining lipoproteins from the circulation, LSR also contributes to the regulation of lipid distribution between the liver and the peripheral tissues.

\subsection{LSR's physiological role}

\subsubsection{Clearance of TG-rich lipoproteins}

The in vivo data described above clearly point towards LSR playing an important role in the removal of TG-rich lipoproteins during the postprandial phase, a time in which there is considerable influx of chylomicrons containing dietary-derived lipids. As these particles enter the portal system, they are acted upon by the hepatic and lipoprotein lipases anchored to the endothelium by HSPG. The resulting hydrolysis of the TG core leads to 
the release of FFA in the highly fenestrated space of Disse. This increased influx of FFA results in optimal activity of LSR, thus allowing the rapid removal of TG-rich particles and their remnants through this pathway. LSR therefore acts downstream of the lipolytic process as a hepatic receptor for the removal of TG-rich particles from the circulation (Figure 4). This conclusion is supported by a recent paper which reported that the removal of apoB-containing lipoproteins was inhibited in animals with reduced sulfation of heparan sulfate proteoglycans in the liver (MacArthur et al., 2007). Indeed, it was suggested that the removal of lipoproteins was mediated by a downstream pathway independent of the LDL-R or LRP1 (Mahley \& Huang, 2007).

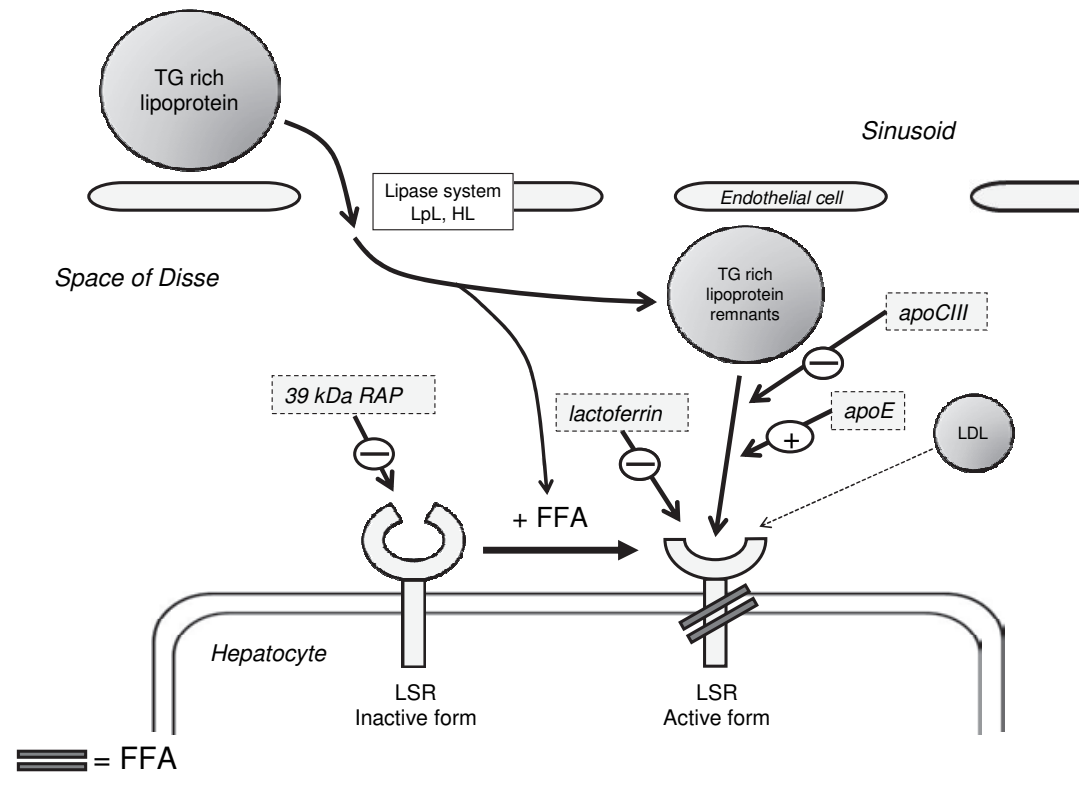

Fig. 4. Diagram for LSR physiological function. During the postprandial phase, there is increased influx of chylomicrons (TG-rich lipoprotein) into the space of Disse, providing substrate for the lipase system (LpL and hepatic lipase, HL). This produces high levels of FFA, which activate LSR, leading to a conformational change exposing an apoB,E binding site for the TG rich particles and/or their remnants. A similar mechanism could occur for TG-rich VLDL. Evidence shows that different proteins (39 kDa RAP, lactoferrin or apoCIII) that can lead to increased plasma TG levels can also affect LSR activity. LSR can also bind apoB of LDL, and may serve as an LDL-receptor independent pathway, most particularly in conditions in which LDL-R is deficient or inactive.

\subsubsection{LDL-receptor independent pathway}

Although acting principally as a receptor for TG-rich lipoproteins, LSR can also bind and endocytose LDL. Its ability to recognize CHD-treated LDL clearly distinguishes this receptor from the LDL-R. If LSR participates in the removal of LDL, it can occur but only under certain conditions. Indeed, LDL is a cholesterol-rich particle and contains very low levels of TG, and thus is not a preferred substrate for lipases. It therefore would not be 
able to generate sufficient lipolytic products to activate LSR, and its removal would occur primarily via the LDL-R. During the postprandial phase, the high influx of FFA in the space of Disse due to lipolytic activity on chylomicrons would inhibit binding of LDL to the LDL-R, while at the same time activating LSR. LDL could therefore be internalized by LSR during the postprandial phase, but only if concentrations are sufficiently high to be able to compete with the higher affinity TG-rich lipoproteins for binding to LSR (Figure 4). Indeed, this hypothesis is supported by the increase in LDL and plasma cholesterol observed in $\mathrm{LSR}^{+/-}$mice on a high-fat cholesterol-containing diet (Yen et al., 2008b), as well as the increased plasma cholesterol following specific hepatic LSR knockout (Narvekar et al., 2009).

This could provide an explanation for the large amounts of LDL that are cleared in FH subjects lacking the LDL receptor. Indeed, J Shepherd and colleagues postulated that this occurred via an LDL-R independent pathway based on their kinetic studies using CHDLDL (Simons et al., 1975). However, this liver-specific receptor-mediated process that was able to remove large quantities of LDL in both humans and animal models remained unidentified at the time.

The LSR model therefore addresses two issues concerning 1) the removal of apoB,Econtaining TG-rich lipoproteins and 2) the clearance of LDL through an LDL-receptor independent pathway with the liver as the final destination.

\subsection{Regulation of LSR}

\subsubsection{Leptin regulation of postprandial lipemia through its effect of LSR}

In the in vivo studies described above, $\mathrm{LSR}^{+/-}$mice demonstrated increased weight gain and a disproportionate increase in leptin levels with age, suggesting a potential connection between leptin and LSR. Leptin is an adipokine that plays a key role in the regulation of food intake and energy storage. Leptin exerts its anorectic effect at the level of the central nervous system by acting on hypothalamic neurons through its interaction with the long form of its receptor, ObRb. This binding leads to increased expression of a-melanocyte stimulating hormone (a-MSH), a potent appetite inhibitor. However, leptin has also been described as a potent stimulator of synaptic transmission, by increasing N-methyl-Daspartate (NMDA) receptor at the cell surface (Moult et al., 2011; Oomura et al., 2006), neuroprotection and neurogenesis (Garza et al., 2008). Hence, leptin could represent much more than a simple on-off switch system controlling food intake and appetite behavior.

The leptin receptor family is widely expressed in many tissue types, including the liver, and leptin itself has been shown to exert other peripheral effects including insulin production by the pancreas (Kahn et al., 2005; Morioka et al., 2007). The distention of the stomach following a meal can lead to increased leptin secretion by adipocytes, thus controlling appetite and energy storage, consistent with its effect as a satiety factor. It was recently demonstrated that leptin can regulate postprandial lipemia by increasing hepatic LSR protein levels (Stenger et al., 2010). Indeed, physiological concentrations of leptin (1 to $10 \mathrm{ng} / \mathrm{mL}$ ) significantly and rapidly (within $1 \mathrm{~h}$ ), increased LSR protein levels in vitro in Hepa1-6 cells. The leptin effect on LSR was confirmed in vivo in wild-type mice injected intra-peritoneally 8 days with leptin. Evidence indicated that leptin mediated this effect by promoting $l s r$ gene transcription through the canonical MAPK/ERK pathway that is activated following leptin interaction with its 
receptor. Interestingly, these leptin-treated mice displayed lower body mass, despite no significant change in food intake. Furthermore, endogenous liver TG output in the form of VLDL was higher, most likely to deliver energy substrate to the peripheral tissues. Thus, during the postprandial phase, leptin directly affects dietary lipid metabolism and storage through its action on LSR at the liver. This mechanism represents a lever for the regulation of dietary lipid uptake, degradation and distribution, thus contributing to maintaining an appropriate lipid homeostasis (Stenger et al., 2010) (Figure 5A).

A

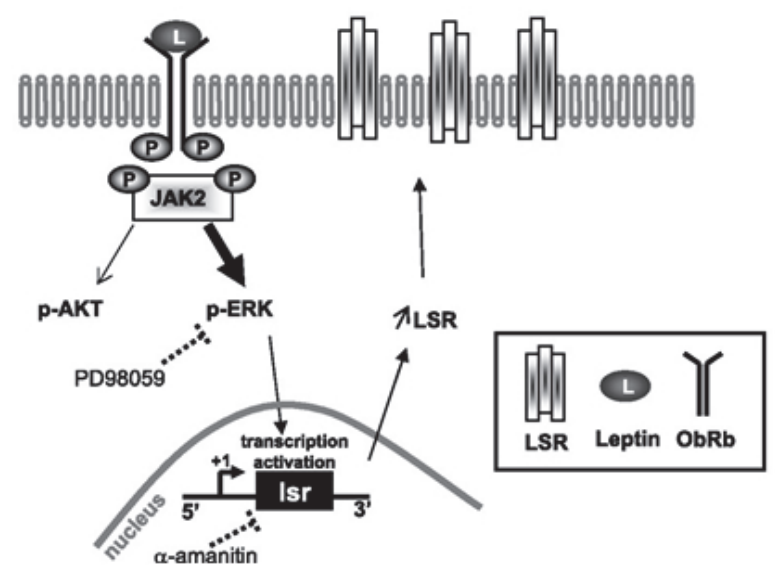

B

- Physiological state (e.g.after a meal)

Leptin $\longrightarrow \uparrow \uparrow \uparrow$ hepatic LSR

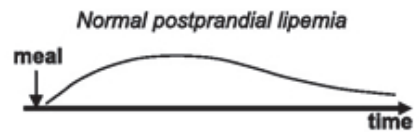

- Dysfunctional (e.g. leptin resistance)

Leptin $\mathrm{X} \rightarrow$ hepatic LSR

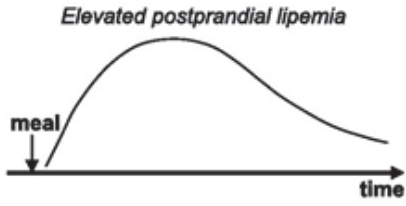

Fig. 5. Schematic diagram for leptin-mediated up-regulation of LSR and potential consequences on postprandial lipemia. A) We propose that the canonical leptin-induced signaling pathway involving phosphorylation of ERK leads to increased transcription of the lsr gene and increased protein levels of LSR at the surface of hepatocyte membranes. B) Under normal conditions, physiological levels of leptin are sufficient to maintain an optimal amount of LSR at the cell surface, permitting clearance of TG-rich lipoproteins during the postprandial phase. However, when leptin interaction with its receptor in the liver is impaired, such as in leptin resistance often observed in obesity, LSR protein levels at the cell surface may no longer be optimal, leading to decreased efficiency in removing lipids from the cell surface, resulting in elevated postprandial lipemia (Stenger et al, 2010, reproduced with permission from Faseb J).

\subsection{Other roles of LSR}

Other studies have recently appeared reporting other biological activities associated with LSR. LSR has been shown to be critical for the formation of tight tricellular contacts in epithelial cells, implying that this receptor is important for the maintenance of epithelial barrier function (Masuda et al., 2011). In view of the multimericity of LSR, it will prove interesting to determine the role of each of the LSR polypeptide subunits in the formation of these cellular junctions. A function has been identified for the full-length LSR a subunit as host receptor for the binary toxin, Clostridium difficile transferase (CDT) (Papatheodorou et 
al., 2011). By using a genome-wide haploid genetic screen on a derivative cell line of the human leukemia cell line KBM7, HAP1, the authors identified LSR as the potential host receptor, and then demonstrated increased reactivity to the toxin in cells expressing LSR. This would therefore point towards a specific role for one of the polypeptides of LSR. It remains however to determine if the other LSR subunits also demonstrate this activity.

LSR expression was found to be inducible by p53 (Jazag et al., 2005; Kannan et al., 2001), and is specifically expressed in certain cancers, including bladder and colon (Herbsleb et al., 2008), which would suggest a role during cancer development. siRNA studies used to inhibit LSR expression in bladder cancer cells led towards increased invasion capacity and cell motility of the cells, suggesting that p53-induced LSR expression may be aimed towards inhibiting the cancerous properties of cells. Additional studies remain to determine LSR's exact role in such circumstances.

Finally, a homolog to LSR was identified by positional cloning with similar alternativelysliced mRNA products, that could potentially relate to the susceptibility of mice to type 2 diabetes (Dokmanovic-Chouinard et al., 2008). Indeed, LSR does not demonstrate any distinct homology to other known receptors, which is why little is known about the relationship between its structure and function. The embryonic lethality of LSR when both alleles are absent does show that this gene and its protein product(s) are essential for development and viability of the embryo and newborn. While this may be due in part to its function as a lipoprotein receptor, it may also be related to the different functions identified here involving the integrity of tricellular junctions, as well as a role in the cell cycle.

\section{LSR as molecular link between hyperlipidemia, obesity and atherosclerosis}

Currently, all data on the physiological role of LSR are based on cell and animal models. The role of leptin in the regulation of LSR as well as the change in distribution of tissue lipids led towards the hypothesis that LSR could provide a molecular link between hyperlipidemia and obesity. Indeed, it was found that LSR expression was significantly diminished in obese mouse models, including the $o b / o b, d b / d b$ and diet-induced obese (DIO) mouse (Narvekar et $a l ., 2009$; Yen et al., 2008a). If leptin either by its absence $(o b / o b)$ or due to a leptin resistance $(d b / d b$ or DIO) is unable to increase LSR levels during the postprandial phase, this could lead to suboptimal levels of this receptor. This in turn could explain the abnormalities found in plasma lipid profile often associated with obesity, most notably in the form of increased plasma TG and elevated postprandial lipemia (Figure 5B).

The LSR+/- animal model demonstrates that even with 50\% of LSR protein levels, this can lead eventually to increased weight gain and body fat mass. These changes are relatively small during early adulthood, but can develop with time into overweight issues leading to obesity, as was observed in aging LSR ${ }^{+/-}$female mice (Stenger et al., 2010). In addition, if dietary fat content is increased under conditions in which LSR is sub-optimal, this leads to accelerated accumulation of fat mass. Interestingly, $\mathrm{LSR}^{+/-}$mice on a 10-wk high fat diet exhibited both hyperleptinemia and impaired phosphorylation of the ERK kinase pathway, associated with a decrease in hepatic leptin receptor expression, as compared to agematched LSR ${ }^{+/+}$littermates on the same diet. These results suggested that the low levels of LSR are directly associated with the appearance of a high-fat diet-induced peripheral leptin 
resistance, for which the mechanisms remain to be elucidated. Peripheral leptin resistance combined with suboptimal levels of LSR during the critical moment of the postprandial phase leads to decreased efficiency in the removal of these atherogenic TG-rich lipoproteins from the circulation, as witnessed by the increased lipid deposits in the aorta of LSR + - mice versus controls on a high fat and cholesterol-containing diet. (Yen et al., 2008). It remains to characterize the physiopathology of these lipid deposits and the molecular mechanisms involved. Nevertheless, together these data show significant modifications in lipid status directly related to LSR that may explain the link between hyperlipidemia and obesity, two significant risk factors for atherosclerosis.

\section{Conclusions and perspectives}

This chapter describes the biochemical characterization and identification of a receptor activated by FFA that plays an important role in lipid homeostasis as receptor for TG-rich lipoproteins during the postprandial phase. Its role in the removal of dietary lipids in the form of chylomicrons from the circulation directly impacts on lipid distribution in the peripheral tissues.

It remains to be determined the importance of LSR in man. Numerous loci have been associated with obesity, body mass index and adiposity, including that located on chromosome 19q13, the loci on which the lsr gene is located. Indeed, linkage studies have identified this region as being associated with TG levels and obesity (Feitosa et al., 2006; Long et al., 2003). This locus has also been identified to contribute to serum lipid levels and dyslipidemia in genome wide association studies (Aulchenko et al., 2009; Kathiresan et al., 2009). It now remains to identify patients with deficiencies in LSR. It is unlikely that patients completely lacking LSR will be identified, since absence of this gene is lethal. Instead, it is possible that patients with genetic polymorphisms of the LSR gene leading to dysfunctional LSR may be discovered that are associated with hypertriglyceridemia or mixed hyperlipidemia.

A majority of research has focused on elevated LDL cholesterol levels, which is an established risk factor for cardiovascular disease. The delineation of the role of LDL-R, as well as the discovery of the statins led to a better understanding in the control of cholesterol homeostasis (Goldstein \& Brown, 2009). This, combined with an heightened public awareness of the increased risk of cardiovascular disease associated with high cholesterol, led to a steady decline in average plasma cholesterol levels in recent years. Nevertheless, cardiovascular disease remains top in the list of principal causes for mortality. Other therapeutic strategies have not proven to be conclusive (Couzin, 2008), demonstrating that other potential targets are needed for the development of other therapeutic strategies. Elevated postprandial lipemia is often observed in both obesity and patients with coronary heart disease. Indeed, TGs are an independent risk factor for cardiovascular disease (Goldberg et al., 2011; Lopez-Miranda et al., 2006). Such being the case, it is also important to find new ways to treat hypertriglyceridemia or mixed hyperlipidemia.

The LSR model provides new insight in the molecular mechanisms involved in the development of hyperlipidemia and represents a molecular between hyperlipidemia, weight gain, and atherosclerosis. Further investigation is required to understand the underlying regulatory pathways involved. Nevertheless, it is clear that LSR is a new and promising 
therapeutic target for the treatment of mixed hyperlipidemia. Optimal activation of LSR by preventive or therapeutic means can be envisaged to normalize clearance of lipoproteins during the postprandial lipemia, thereby preventing the accumulation of these high-risk lipid particles in the circulation.

\section{Acknowledgements}

The work described here represents the efforts of many, but most particularly that of Bernard E. Bihain, who discovered this receptor with F.T. Yen. Although he is pursuing other avenues of research, he will not be forgotten for his work and dedication in bringing to light a novel lipoprotein receptor, this despite enormous skepticism from the scientific community. The authors also dedicate this chapter to Patrice André, Nelly Clossais-Besnard, and Vincent Lotteau of INSERM U391 in Rennes where the gene was identified, and proven not until much later to be the right one.

\section{References}

Aalto-Setala, K., Fisher, E.A., Chen, X., Chajek-Shaul, T., Hayek, T., Zechner, R., Walsh, A., Ramakrishnan, R., Ginsberg, H.N. \& Breslow, J.L. (1992). Mechanism of hypertriglyceridemia in human apolipoprotein (apo) CIII transgenic mice. Diminished very low density lipoprotein fractional catabolic rate associated with increased apo CIII and reduced apo E on the particles. J Clin Invest, Vol. 90, No. 5, pp. 1889-1900

Attie, A.D., Pittman, R.C. \& Steinberg, D. (1982). Hepatic catabolism of low density lipoprotein: mechanisms and metabolic consequences. Hepatology, Vol. 2, No. 2, pp. 269-281

Aulchenko, Y.S., Ripatti, S., Lindqvist, I., Boomsma, D., Heid, I.M., Pramstaller, P.P., Penninx, B.W., Janssens, A.C., Wilson, J.F., Spector, T., Martin, N.G., Pedersen, N.L., Kyvik, K.O., Kaprio, J., Hofman, A., Freimer, N.B., Jarvelin, M.R., Gyllensten, U., Campbell, H., Rudan, I., Johansson, A., Marroni, F., Hayward, C., Vitart, V., Jonasson, I., Pattaro, C., Wright, A., Hastie, N., Pichler, I., Hicks, A.A., Falchi, M., Willemsen, G., Hottenga, J.J., de Geus, E.J., Montgomery, G.W., Whitfield, J., Magnusson, P., Saharinen, J., Perola, M., Silander, K., Isaacs, A., Sijbrands, E.J., Uitterlinden, A.G., Witteman, J.C., Oostra, B.A., Elliott, P., Ruokonen, A., Sabatti, C., Gieger, C., Meitinger, T., Kronenberg, F., Doring, A., Wichmann, H.E., Smit, J.H., McCarthy, M.I., van Duijn, C.M. \& Peltonen, L. (2009). Loci influencing lipid levels and coronary heart disease risk in 16 European population cohorts. Nat Genet, Vol. 41, No. 1, pp. 47-55

Bazan, J.F. (1990). Structural design and molecular evolution of a cytokine receptor superfamily. Proc Natl Acad Sci U S A, Vol. 87, No. 18, pp. 6934-6938

Beisiegel, U., Weber, W., Havinga, J.R., Ihrke, G., Hui, D.Y., Wernette-Hammond, M.E., Turck, C.W., Innerarity, T.L. \& Mahley, R.W. (1988). Apolipoprotein E-binding proteins isolated from dog and human liver. Arteriosclerosis, Vol. 8, No. 3, pp. 288-297

Beisiegel, U., Weber, W., Ihrke, G., Herz, J. \& Stanley, K.K. (1989). The LDL-receptor-related protein, LRP, is an apolipoprotein E-binding protein. Nature, Vol. 341, No. 6238, pp. $162-164$ 
Berr, F. \& Kern, F., Jr. (1984). Plasma clearance of chylomicrons labeled with retinyl palmitate in healthy human subjects. J Lipid Res, Vol. 25, No. 8, pp. 805-812

Bihain, B.E., Deckelbaum, R.J., Yen, F.T., Gleeson, A.M., Carpentier, Y.A. \& Witte, L.D. (1989). Unesterified fatty acids inhibit the binding of low density lipoproteins to the human fibroblast low density lipoprotein receptor. J Biol Chem, Vol. 264, No. 29, pp. 17316-17321

Bihain, B.E. \& Yen, F.T. (1992). Free fatty acids activate a high-affinity saturable pathway for degradation of low-density lipoproteins in fibroblasts from a subject homozygous for familial hypercholesterolemia. Biochemistry, Vol. 31, No. 19, pp. 4628-4636

Bihain, B.E. \& Yen, F.T. (1998). The lipolysis stimulated receptor: a gene at last. Curr Opin Lipidol, Vol. 9, No. 3, pp. 221-224

Bihain, B.E. \& Yen, F.T. (2005). Receptors for circulating lipoproteins (Article in French). Médecine Clinique endocrinologie \& diabète, Vol. Special edition, No. pp. 2-6

Brown, M.S. \& Goldstein, J.L. (1986). A receptor-mediated pathway for cholesterol homeostasis. Science, Vol. 232, No. 4746, pp. 34-47

Brown, M.S. \& Goldstein, J.L. (1997). The SREBP pathway: regulation of cholesterol metabolism by proteolysis of a membrane-bound transcription factor. Cell, Vol. 89, No. 3, pp. 331-340

Chen, W.J., Goldstein, J.L. \& Brown, M.S. (1990). NPXY, a sequence often found in cytoplasmic tails, is required for coated pit-mediated internalization of the low density lipoprotein receptor. J Biol Chem, Vol. 265, No. 6, pp. 3116-3123

Cortner, J.A., Coates, P.M., Le, N.A., Cryer, D.R., Ragni, M.C., Faulkner, A. \& Langer, T. (1987). Kinetics of chylomicron remnant clearance in normal and in hyperlipoproteinemic subjects. J Lipid Res, Vol. 28, No. 2, pp. 195-206

Couzin, J. (2008). Clinical trials and tribulations. Cholesterol veers off script. Science, Vol. 322, No. 5899, pp. 220-223

de Faria, E., Fong, L.G., Komaromy, M. \& Cooper, A.D. (1996). Relative roles of the LDL receptor, the LDL receptor-like protein, and hepatic lipase in chylomicron remnant removal by the liver. J Lipid Res, Vol. 37, No. 1, pp. 197-209

Dietrich, J., Hou, X., Wegener, A.M. \& Geisler, C. (1994). CD3 gamma contains a phosphoserine-dependent di-leucine motif involved in down-regulation of the $\mathrm{T}$ cell receptor. Embo J, Vol. 13, No. 9, pp. 2156-2166

Dokmanovic-Chouinard, M., Chung, W.K., Chevre, J.C., Watson, E., Yonan, J., Wiegand, B., Bromberg, Y., Wakae, N., Wright, C.V., Overton, J., Ghosh, S., Sathe, G.M., Ammala, C.E., Brown, K.K., Ito, R., LeDuc, C., Solomon, K., Fischer, S.G. \& Leibel, R.L. (2008). Positional cloning of "Lisch-Like", a candidate modifier of susceptibility to type 2 diabetes in mice. PLoS Genet, Vol. 4, No. 7, pp. e1000137

Eisenberg, S., Sehayek, E., Olivecrona, T. \& Vlodavsky, I. (1992). Lipoprotein lipase enhances binding of lipoproteins to heparan sulfate on cell surfaces and extracellular matrix. J Clin Invest, Vol. 90, No. 5, pp. 2013-2021

Feitosa, M.F., Rice, T., North, K.E., Kraja, A., Rankinen, T., Leon, A.S., Skinner, J.S., Blangero, J., Bouchard, C. \& Rao, D.C. (2006). Pleiotropic QTL on chromosome 19q13 for triglycerides and adiposity: the HERITAGE Family Study. Atherosclerosis, Vol. 185, No. 2, pp. 426-432

Garza, J.C., Guo, M., Zhang, W. \& Lu, X.Y. (2008). Leptin increases adult hippocampal neurogenesis in vivo and in vitro. J Biol Chem, Vol. 283, No. 26, pp. 18238-18247 
Goldberg, I.J., Eckel, R.H. \& McPherson, R. (2011). Triglycerides and heart disease: still a hypothesis? Arterioscler Thromb Vasc Biol, Vol. 31, No. 8, pp. 1716-1725

Goldstein, J.L., Basu, S.K. \& Brown, M.S. (1983). Receptor-mediated endocytosis of lowdensity lipoprotein in cultured cells. Methods Enzymol, Vol. 98, No. pp. 241-260

Goldstein, J.L. \& Brown, M.S. (2009). The LDL receptor. Arterioscler Thromb Vasc Biol, Vol. 29, No. 4 , pp. $431-438$

Goldstein, J.L., Hobbs, H.H. \& Brown, M.S. (1995). Familial hypercholesterolemia, In: The Metabolic and Molecular Bases of Inherited Disease, Scriver, C. R., Beaudet, A. L., Sly, W. S. and Valle, D., pp. 1981-2030, McGraw-Hill, Inc., New York

Havel, R.J. \& Kane, J.P. (1995). Structure and Metabolism of plasma lipoproteins, In: The Metabolic and Molecular Bases of Inherited Disease, Scriver, C. R., Beaudet, A. L., Sly, W. S. and Valle, D., pp. 1841-1851, McGraw-Hill, Inc., New York

Herbsleb, M., Birkenkamp-Demtroder, K., Thykjaer, T., Wiuf, C., Hein, A.M., Orntoft, T.F. \& Dyrskjot, L. (2008). Increased cell motility and invasion upon knockdown of lipolysis stimulated lipoprotein receptor (LSR) in SW780 bladder cancer cells. BMC Med Genomics, Vol. 1, No. pp. 31

Herz, J., Clouthier, D.E. \& Hammer, R.E. (1992). LDL receptor-related protein internalizes and degrades uPA-PAI-1 complexes and is essential for embryo implantation. Cell, Vol. 71, No. 3, pp. 411-421

Herz, J., Goldstein, J.L., Strickland, D.K., Ho, Y.K. \& Brown, M.S. (1991). 39-kDa protein modulates binding of ligands to low density lipoprotein receptor-related protein/alpha 2-macroglobulin receptor. J Biol Chem, Vol. 266, No. 31, pp. 2123221238

Herz, J., Hamann, U., Rogne, S., Myklebost, O., Gausepohl, H. \& Stanley, K.K. (1988). Surface location and high affinity for calcium of a 500-kd liver membrane protein closely related to the LDL-receptor suggest a physiological role as lipoprotein receptor. Embo J, Vol. 7, No. 13, pp. 4119-4127

Herz, J. \& Strickland, D.K. (2001). LRP: a multifunctional scavenger and signaling receptor. J Clin Invest, Vol. 108, No. 6, pp. 779-784

Hobbs, H.H., Brown, M.S., Russell, D.W., Davignon, J. \& Goldstein, J.L. (1987). Deletion in the gene for the low-density-lipoprotein receptor in a majority of French Canadians with familial hypercholesterolemia. N Engl J Med, Vol. 317, No. 12, pp. 734-737

Hofmann, S.M., Zhou, L., Perez-Tilve, D., Greer, T., Grant, E., Wancata, L., Thomas, A., Pfluger, P.T., Basford, J.E., Gilham, D., Herz, J., Tschop, M.H. \& Hui, D.Y. (2007). Adipocyte LDL receptor-related protein-1 expression modulates postprandial lipid transport and glucose homeostasis in mice. J Clin Invest, Vol. 117, No. 11, pp. 32713282

Huettinger, M., Retzek, H., Eder, M. \& Goldenberg, H. (1988). Characteristics of chylomicron remnant uptake into rat liver. Clin Biochem, Vol. 21, No. 2, pp. 87-92

Ishibashi, S., Perrey, S., Chen, Z., Osuga, J., Shimada, M., Ohashi, K., Harada, K., Yazaki, Y. \& Yamada, N. (1996). Role of the low density lipoprotein (LDL) receptor pathway in the metabolism of chylomicron remnants. A quantitative study in knockout mice lacking the LDL receptor, apolipoprotein E, or both. J Biol Chem, Vol. 271, No. 37, pp. 22422-22427 
Ito, Y., Azrolan, N., O'Connell, A., Walsh, A. \& Breslow, J.L. (1990). Hypertriglyceridemia as a result of human apo CIII gene expression in transgenic mice. Science, Vol. 249, No. 4970, pp. 790-793

Jazag, A., Ijichi, H., Kanai, F., Imamura, T., Guleng, B., Ohta, M., Imamura, J., Tanaka, Y., Tateishi, K., Ikenoue, T., Kawakami, T., Arakawa, Y., Miyagishi, M., Taira, K., Kawabe, T. \& Omata, M. (2005). Smad4 silencing in pancreatic cancer cell lines using stable RNA interference and gene expression profiles induced by transforming growth factor-beta. Oncogene, Vol. 24, No. 4, pp. 662-671

Kahn, B.B., Alquier, T., Carling, D. \& Hardie, D.G. (2005). AMP-activated protein kinase: ancient energy gauge provides clues to modern understanding of metabolism. Cell Metab, Vol. 1, No. 1, pp. 15-25

Kannan, K., Amariglio, N., Rechavi, G., Jakob-Hirsch, J., Kela, I., Kaminski, N., Getz, G., Domany, E. \& Givol, D. (2001). DNA microarrays identification of primary and secondary target genes regulated by p53. Oncogene, Vol. 20, No. 18, pp. 2225-2234

Kathiresan, S., Willer, C.J., Peloso, G.M., Demissie, S., Musunuru, K., Schadt, E.E., Kaplan, L., Bennett, D., Li, Y., Tanaka, T., Voight, B.F., Bonnycastle, L.L., Jackson, A.U., Crawford, G., Surti, A., Guiducci, C., Burtt, N.P., Parish, S., Clarke, R., Zelenika, D., Kubalanza, K.A., Morken, M.A., Scott, L.J., Stringham, H.M., Galan, P., Swift, A.J., Kuusisto, J., Bergman, R.N., Sundvall, J., Laakso, M., Ferrucci, L., Scheet, P., Sanna, S., Uda, M., Yang, Q., Lunetta, K.L., Dupuis, J., de Bakker, P.I., O'Donnell, C.J., Chambers, J.C., Kooner, J.S., Hercberg, S., Meneton, P., Lakatta, E.G., Scuteri, A., Schlessinger, D., Tuomilehto, J., Collins, F.S., Groop, L., Altshuler, D., Collins, R., Lathrop, G.M., Melander, O., Salomaa, V., Peltonen, L., Orho-Melander, M., Ordovas, J.M., Boehnke, M., Abecasis, G.R., Mohlke, K.L. \& Cupples, L.A. (2009). Common variants at 30 loci contribute to polygenic dyslipidemia. Nat Genet, Vol. 41, No. 1, pp. 56-65

Kita, T., Goldstein, J.L., Brown, M.S., Watanabe, Y., Hornick, C.A. \& Havel, R.J. (1982). Hepatic uptake of chylomicron remnants in WHHL rabbits: a mechanism genetically distinct from the low density lipoprotein receptor. Proc Natl Acad Sci U $S$ A, Vol. 79, No. 11, pp. 3623-3627

Kowal, R.C., Herz, J., Goldstein, J.L., Esser, V. \& Brown, M.S. (1989). Low density lipoprotein receptor-related protein mediates uptake of cholesteryl esters derived from apoprotein E-enriched lipoproteins. Proc Natl Acad Sci U S A, Vol. 86, No. 15, pp. 5810-5814

Long, J.R., Liu, P.Y., Liu, Y.J., Lu, Y., Xiong, D.H., Elze, L., Recker, R.R. \& Deng, H.W. (2003). APOE and TGF-beta1 genes are associated with obesity phenotypes. J Med Genet, Vol. 40, No. 12, pp. 918-924

Lopez-Miranda, J., Perez-Martinez, P., Marin, C., Moreno, J.A., Gomez, P. \& Perez-Jimenez, F. (2006). Postprandial lipoprotein metabolism, genes and risk of cardiovascular disease. Curr Opin Lipidol, Vol. 17, No. 2, pp. 132-138

MacArthur, J.M., Bishop, J.R., Stanford, K.I., Wang, L., Bensadoun, A., Witztum, J.L. \& Esko, J.D. (2007). Liver heparan sulfate proteoglycans mediate clearance of triglyceriderich lipoproteins independently of LDL receptor family members. J Clin Invest, Vol. 117, No. 1, pp. 153-164

Maeda, N., Li, H., Lee, D., Oliver, P., Quarfordt, S.H. \& Osada, J. (1994). Targeted disruption of the apolipoprotein C-III gene in mice results in hypotriglyceridemia and 
protection from postprandial hypertriglyceridemia. J Biol Chem, Vol. 269, No. 38, pp. 23610-23616

Mahley, R.W. \& Huang, Y. (2007). Atherogenic remnant lipoproteins: role for proteoglycans in trapping, transferring, and internalizing. J Clin Invest, Vol. 117, No. 1, pp. 94-98

Mann, C.J., Khallou, J., Chevreuil, O., Troussard, A.A., Guermani, L.M., Launay, K., Delplanque, B., Yen, F.T. \& Bihain, B.E. (1995). Mechanism of activation and functional significance of the lipolysis-stimulated receptor. Evidence for a role as chylomicron remnant receptor. Biochemistry, Vol. 34, No. 33, pp. 10421-10431

Mann, C.J., Troussard, A.A., Yen, F.T., Hannouche, N., Najib, J., Fruchart, J.C., Lotteau, V., Andre, P. \& Bihain, B.E. (1997). Inhibitory effects of specific apolipoprotein C-III isoforms on the binding of triglyceride-rich lipoproteins to the lipolysis-stimulated receptor. J Biol Chem, Vol. 272, No. 50, pp. 31348-31354

Masuda, S., Oda, Y., Sasaki, H., Ikenouchi, J., Higashi, T., Akashi, M., Nishi, E. \& Furuse, M. (2011). LSR defines cell corners for tricellular tight junction formation in epithelial cells. J Cell Sci, Vol. 124, No. Pt 4, pp. 548-555

Medh, J.D., Fry, G.L., Bowen, S.L., Pladet, M.W., Strickland, D.K. \& Chappell, D.A. (1995). The 39-kDa receptor-associated protein modulates lipoprotein catabolism by binding to LDL receptors. J Biol Chem, Vol. 270, No. 2, pp. 536-540

Mesli, S., Javorschi, S., Berard, A.M., Landry, M., Priddle, H., Kivlichan, D., Smith, A.J., Yen, F.T., Bihain, B.E. \& Darmon, M. (2004). Distribution of the lipolysis stimulated receptor in adult and embryonic murine tissues and lethality of LSR-/- embryos at 12.5 to 14.5 days of gestation. Eur J Biochem, Vol. 271, No. 15, pp. 3103-3114

Moestrup, S.K. \& Gliemann, J. (1991). Analysis of ligand recognition by the purified alpha 2macroglobulin receptor (low density lipoprotein receptor-related protein). Evidence that high affinity of alpha 2-macroglobulin-proteinase complex is achieved by binding to adjacent receptors. J Biol Chem, Vol. 266, No. 21, pp. 1401114017

Mokuno, H., Brady, S., Kotite, L., Herz, J. \& Havel, R.J. (1994). Effect of the 39-kDa receptorassociated protein on the hepatic uptake and endocytosis of chylomicron remnants and low density lipoproteins in the rat. J Biol Chem, Vol. 269, No. 18, pp. 1323813243

Morioka, T., Asilmaz, E., Hu, J., Dishinger, J.F., Kurpad, A.J., Elias, C.F., Li, H., Elmquist, J.K., Kennedy, R.T. \& Kulkarni, R.N. (2007). Disruption of leptin receptor expression in the pancreas directly affects beta cell growth and function in mice. $J$ Clin Invest, Vol. 117, No. 10, pp. 2860-2868

Moult, P.R., Cross, A., Santos, S.D., Carvalho, A.L., Lindsay, Y., Connolly, C.N., Irving, A.J., Leslie, N.R. \& Harvey, J. (2011). Leptin regulates AMPA receptor trafficking via PTEN inhibition. J Neurosci, Vol. 30, No. 11, pp. 4088-4101

Mulder, M., Lombardi, P., Jansen, H., van Berkel, T.J., Frants, R.R. \& Havekes, L.M. (1993). Low density lipoprotein receptor internalizes low density and very low density lipoproteins that are bound to heparan sulfate proteoglycans via lipoprotein lipase. J Biol Chem, Vol. 268, No. 13, pp. 9369-9375

Narvekar, P., Berriel Diaz, M., Krones-Herzig, A., Hardeland, U., Strzoda, D., Stohr, S., Frohme, M. \& Herzig, S. (2009). Liver-specific loss of lipolysis-stimulated lipoprotein receptor triggers systemic hyperlipidemia in mice. Diabetes, Vol. 58, No. 5, pp. 1040-1049 
Oomura, Y., Hori, N., Shiraishi, T., Fukunaga, K., Takeda, H., Tsuji, M., Matsumiya, T., Ishibashi, M., Aou, S., Li, X.L., Kohno, D., Uramura, K., Sougawa, H., Yada, T., Wayner, M.J. \& Sasaki, K. (2006). Leptin facilitates learning and memory performance and enhances hippocampal CA1 long-term potentiation and CaMK II phosphorylation in rats. Peptides, Vol. 27, No. 11, pp. 2738-2749

Papatheodorou, P., Carette, J.E., Bell, G.W., Schwan, C., Guttenberg, G., Brummelkamp, T.R. \& Aktories, K. (2011). Lipolysis-stimulated lipoprotein receptor (LSR) is the host receptor for the binary toxin Clostridium difficile transferase (CDT). Proc Natl Acad Sci U S A, Vol. 108, No. 39, pp. 16422-16427

Ramprasad, M.P., Li, R., Gianturco, S.H. \& Bradley, W.A. (1995). Purification of the human THP-1 monocyte-macrophage triglyceride-rich lipoprotein receptor. Biochem Biophys Res Commun, Vol. 210, No. 2, pp. 491-497

Rohlmann, A., Gotthardt, M., Hammer, R.E. \& Herz, J. (1998). Inducible inactivation of hepatic LRP gene by cre-mediated recombination confirms role of LRP in clearance of chylomicron remnants. J Clin Invest, Vol. 101, No. 3, pp. 689-695

Rubinsztein, D.C., Cohen, J.C., Berger, G.M., van der Westhuyzen, D.R., Coetzee, G.A. \& Gevers, W. (1990). Chylomicron remnant clearance from the plasma is normal in familial hypercholesterolemic homozygotes with defined receptor defects. J Clin Invest, Vol. 86, No. 4, pp. 1306-1312

Sakai, J., Hoshino, A., Takahashi, S., Miura, Y., Ishii, H., Suzuki, H., Kawarabayasi, Y. \& Yamamoto, T. (1994). Structure, chromosome location, and expression of the human very low density lipoprotein receptor gene. J Biol Chem, Vol. 269, No. 3, pp. 2173-2182

Sherrill, B.C. \& Dietschy, J.M. (1978). Characterization of the sinusoidal transport process responsible for uptake of chylomicrons by the liver. J Biol Chem, Vol. 253, No. 6, pp. 1859-1867

Shin, J., Dunbrack, R.L., Jr., Lee, S. \& Strominger, J.L. (1991). Phosphorylation-dependent down-modulation of CD4 requires a specific structure within the cytoplasmic domain of CD4. J Biol Chem, Vol. 266, No. 16, pp. 10658-10665

Simons, L.A., Reichl, D., Myant, N.B. \& Mancini, M. (1975). The metabolism of the apoprotein of plasma low density lipoprotein in familial hyperbetalipoproteinaemia in the homozygous form. Atherosclerosis, Vol. 21, No. 2, pp. 283-298

Soutar, A.K. (1989). Lipoprotein-remnant receptors: second receptor verified? Nature, Vol. 341, No. 6238, pp. 106-107

Stenger, C., Hanse, M., Pratte, D., Mbala, M.L., Akbar, S., Koziel, V., Escanye, M.C., Kriem, B., Malaplate-Armand, C., Olivier, J.L., Oster, T., Pillot, T. \& Yen, F.T. (2010). Upregulation of hepatic lipolysis stimulated lipoprotein receptor by leptin: a potential lever for controlling lipid clearance during the postprandial phase. Faseb J, Vol. 24, No. 11, pp. 4218-4228

Strickland, D.K., Ashcom, J.D., Williams, S., Burgess, W.H., Migliorini, M. \& Argraves, W.S. (1990). Sequence identity between the alpha 2-macroglobulin receptor and low density lipoprotein receptor-related protein suggests that this molecule is a multifunctional receptor. J Biol Chem, Vol. 265, No. 29, pp. 17401-17404 
Troussard, A.A., Khallou, J., Mann, C.J., Andre, P., Strickland, D.K., Bihain, B.E. \& Yen, F.T. (1995). Inhibitory effect on the lipolysis-stimulated receptor of the 39-kDa receptorassociated protein. J Biol Chem, Vol. 270, No. 29, pp. 17068-17071

Villen, J., Beausoleil, S.A., Gerber, S.A. \& Gygi, S.P. (2007). Large-scale phosphorylation analysis of mouse liver. Proc Natl Acad Sci U S A, Vol. 104, No. 5, pp. 1488-1493

Williams, K.J., Fless, G.M., Petrie, K.A., Snyder, M.L., Brocia, R.W. \& Swenson, T.L. (1992). Mechanisms by which lipoprotein lipase alters cellular metabolism of lipoprotein(a), low density lipoprotein, and nascent lipoproteins. Roles for low density lipoprotein receptors and heparan sulfate proteoglycans. J Biol Chem, Vol. 267, No. 19, pp. 13284-13292

Williams, S.E., Ashcom, J.D., Argraves, W.S. \& Strickland, D.K. (1992). A novel mechanism for controlling the activity of alpha 2-macroglobulin receptor/low density lipoprotein receptor-related protein. Multiple regulatory sites for 39-kDa receptorassociated protein. J Biol Chem, Vol. 267, No. 13, pp. 9035-9040

Willnow, T.E., Sheng, Z., Ishibashi, S. \& Herz, J. (1994). Inhibition of hepatic chylomicron remnant uptake by gene transfer of a receptor antagonist. Science, Vol. 264, No. 5164, pp. 1471-1474

Yen, F.T., Mann, C.J., Guermani, L.M., Hannouche, N.F., Hubert, N., Hornick, C.A., Bordeau, V.N., Agnani, G. \& Bihain, B.E. (1994). Identification of a lipolysisstimulated receptor that is distinct from the LDL receptor and the LDL receptorrelated protein. Biochemistry, Vol. 33, No. 5, pp. 1172-1180

Yen, F.T., Masson, M., Clossais-Besnard, N., Andre, P., Grosset, J.M., Bougueleret, L., Dumas, J.B., Guerassimenko, O. \& Bihain, B.E. (1999). Molecular cloning of a lipolysis-stimulated remnant receptor expressed in the liver. J Biol Chem, Vol. 274, No. 19, pp. 13390-13398

Yen, F.T., Masson, M., Roitel, O., Bonnard, L., Notet, V., Pratte, D., Magueur, E. \& Bihain, B.E. (2008a). Elevated posptrandial lipemia and increased apoB-containing lipoproteins in mice with single allele inactivation of hepatic lipolysis stimulated receptor (LSR): Evidence for link between hyperlipidemia, obesity, and atherosclerosis. Arterioscler Thromb Vasc Biol, Vol. 28, No. 6, pp. e36

Yen, F.T., Roitel, O., Bonnard, L., Notet, V., Pratte, D., Stenger, C., Magueur, E. \& Bihain, B.E. (2008b). Lipolysis stimulated lipoprotein receptor: A novel molecular link between hyperlipidemia, weight gain, and atherosclerosis in mice. J Biol Chem, Vol. 283, No. 37, pp. 25650-25659 


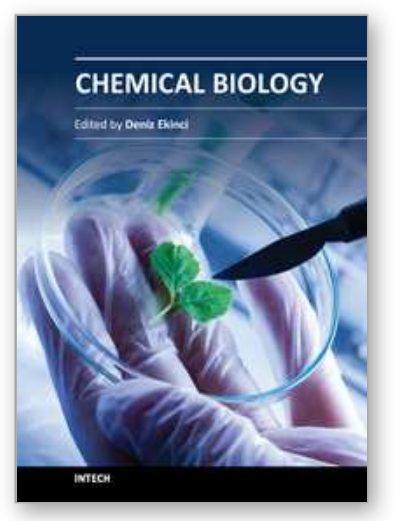

\author{
Chemical Biology \\ Edited by Prof. Deniz Ekinci
}

ISBN 978-953-51-0049-2

Hard cover, 444 pages

Publisher InTech

Published online 17, February, 2012

Published in print edition February, 2012

Chemical biology utilizes chemical principles to modulate systems to either investigate the underlying biology or create new function. Over recent years, chemical biology has received particular attention of many scientists in the life sciences from botany to medicine. This book contains an overview focusing on the research area of protein purification, enzymology, vitamins, antioxidants, biotransformation, gene delivery, signaling, regulation and organization. Particular emphasis is devoted to both theoretical and experimental aspects. The textbook is written by international scientists with expertise in synthetic chemistry, protein biochemistry, enzymology, molecular biology, drug discovery and genetics many of which are active chemical, biochemical and biomedical research. The textbook is expected to enhance the knowledge of scientists in the complexities of chemical and biological approaches and stimulate both professionals and students to dedicate part of their future research in understanding relevant mechanisms and applications of chemical biology.

\title{
How to reference
}

In order to correctly reference this scholarly work, feel free to copy and paste the following:

Christophe Stenger, Catherine Corbier and Frances T. Yen (2012). Structure and Function of the Lipolysis Stimulated Lipoprotein Receptor, Chemical Biology, Prof. Deniz Ekinci (Ed.), ISBN: 978-953-51-0049-2, InTech, Available from: http://www.intechopen.com/books/chemical-biology/structure-and-function-of-thelipolysis-stimulated-lipoprotein-receptor

\section{INTECH}

open science | open minds

\author{
InTech Europe \\ University Campus STeP Ri \\ Slavka Krautzeka 83/A \\ 51000 Rijeka, Croatia \\ Phone: +385 (51) 770447 \\ Fax: +385 (51) 686166 \\ www.intechopen.com
}

\author{
InTech China \\ Unit 405, Office Block, Hotel Equatorial Shanghai \\ No.65, Yan An Road (West), Shanghai, 200040, China \\ 中国上海市延安西路65号上海国际贵都大饭店办公楼 405 单元 \\ Phone: +86-21-62489820 \\ Fax: $+86-21-62489821$
}


(C) 2012 The Author(s). Licensee IntechOpen. This is an open access article distributed under the terms of the Creative Commons Attribution 3.0 License, which permits unrestricted use, distribution, and reproduction in any medium, provided the original work is properly cited. 